\title{
Effects of Phytol, a Branched, Long-Chain Aliphatic Alcohol, on Biochemical Values and on Hepatic Peroxisomal Enzymes of Rats
}

\author{
Takafumi Watanabe and Tetsuya Suga* \\ Department of Clinical Biochemistry, Tokyo College of Pharmacy, \\ Horinouchi 1432-1, Tokyo 192-03, Japan
}

(Received December 13, 1982)

\begin{abstract}
The effects of phytol on biochemical values (triglyceride and cholesterol levels of liver and serum, body weight gain and liver weight), and peroxisomal enzyme activities were investigated in rats. The rats were given phytol orally at the dose of 200 or $500 \mathrm{mg} / \mathrm{kg}$ body weight daily for 3 weeks. The triglyceride and cholesterol levels of the serum of the rats treated with phytol at $500 \mathrm{mg} / \mathrm{kg}$ decreased by 32 and $35 \%$ respectively, while no influence on body weight gain or liver weight was observed. Fatty acyl-CoA oxidase activity and catalase activity in the livers of treated rats were increased by 29 and $20 \%$ at $200 \mathrm{mg} / \mathrm{kg}$, and by 36 and $44 \%$ at $500 \mathrm{mg} / \mathrm{kg}$, respectively. DAmino acid oxidase activity was also increased by $54 \%$ (at $200 \mathrm{mg} / \mathrm{kg}$ ) and $85 \%$ (at $500 \mathrm{mg} / \mathrm{kg}$ ) in treated animals, but the activity of another peroxisomal enzyme, urate oxidase, did not change. On sucrose density gradient centrifugation of the light mitochondrial fractions prepared from the livers of control and treated rats, similar distribution patterns were observed in both samples, but the activities of catalase and fatty acyl-CoA oxidase of peroxisomal fraction of the treated $(500 \mathrm{mg} / \mathrm{kg})$ group were increased by 68 and $45 \%$, respectively. These results suggest that phytol might enhance peroxisomal $\beta$-oxidation and also induce some peroxisomal enzymes, causing change of peroxisomal enzyme compositions.
\end{abstract}

Keywords-peroxisome; phytol; $\beta$-oxidation; fatty acyl-CoA oxidase; sucrose density gradient centrifugation

The finding by Lazarow et al. ${ }^{1)}$ that the cyanide-insensitive fatty acyl-CoA oxidizing system was located in the peroxisomes, indicated that the physiological function of peroxisomes could be related to lipid metabolism. Furthermore, from the results of studies on the substrate specificity ${ }^{2,3)}$ and the activity of the peroxisomal fatty acyl-CoA oxidizing system under various physiological conditions, such as starvation, ${ }^{4)}$ high fat $\operatorname{diet}^{5,6)}$ and diabetes, ${ }^{7)}$ and from the fact that peroxisomes have oxidative metabolizing activity for cholesterol side chain, ${ }^{8)}$ it has been suggested that peroxisomes are involved in lipid metabolism when the living organism urgently needs energy, and contribute to the oxidative degradation of longand branched-chain fatty acids which could not be degraded effectively by mitochondrial $\beta$ oxidation.

Phytol $\left(\Delta^{2}-3,7,-11,15\right.$-tetramethylhexadecanol) is a branched, long-chain aliphatic alcohol contained in large quantities in plants. In 1969 , Steinberg et al. ${ }^{9)}$ showed that a major pathway for phytol metabolism in the rat and in the mouse involved the formation of pristanic acid $(2,6,10,14$-tetramethylpentadecanoic acid), produced by $\alpha$-oxidation of phytanic acid derived from phytol. The pristanic acid is successively degraded by $\beta$-oxidation. Thus, taking into consideration the possibility that the peroxisomal $\beta$-oxidation system may be involved in the metabolism of this compound, we firstly examined the in vivo effects of oral administration of large amounts of phytol on the enzyme composition of rat liver peroxisomes and serum lipid level. 


\section{Experimental}

Phytol was obtained from Tokyo Kasei Kogyo Co. L-Carnitine-HCl was kindly gifted by Otsuka Pharmaceutical Co. Acetyl-CoA and palmitoil-CoA obtained from Sigma Chemical Company, St. Louis, Mo., U.S.A. 5,5'-Dithio-bis(2-nitrobenzoic acid) (DTNB) and dithiothreitol (DTT) were obtained from Wako Pure Chemicals, Osaka, Japan. Other chemicals, all of reagent grade, were obtained from commercial sources.

Animals and Treatment_-Male Wistar rats, weighing 140-150 g, were used. Fifteen animals were divided into three groups. The first and second groups were orally given phytol emulsion $(0.08 \mathrm{~g}$ and $0.2 \mathrm{~g} / \mathrm{ml} 0.5 \%$ gum arabicum). at $200 \mathrm{mg} / \mathrm{kg}$ and $500 \mathrm{mg} / \mathrm{kg}$ body weight, respectively, daily for 3 weeks. The control group was orally given the solvent only at $0.25 \mathrm{ml} / 100 \mathrm{~g}$ body weight. After 3 weeks of administration, the liver was removed, weighed and homogenized in $0.25 \mathrm{M}$ sucrose in a Potter-Elvehjem type homogenizer with a Teflon pestle. Serum was pooled for the determination of triglyceride (TG) and cholesterol contents.

Assay Methods_Liver and serum TG were assayed by the van Handel-Kawade method with a slight modification: Phenylhydrazine- $\mathrm{HCl}$ was used instead of chromotropic acid ${ }^{10)}$ Cholesterol was assayed by the method of Zak-Henly. ${ }^{11)}$ The enzyme activities of catalase, D-amino acid oxidase (DAAO) and urate oxidase were determined according to the method previously reported by Hayashi et al. ${ }^{12)}$ Unit enzyme activities of catalase and urate oxidase were defined as the amounts of the enzymes giving $K=1$, where $K$ is the rate constant of the enzyme. The activity of fatty acyl-CoA oxidase (FAO) was determined by measuring acyl-CoA-dependent $\mathrm{H}_{2} \mathrm{O}_{2}$ generation using a modification of the method described by Allain et al. ${ }^{13)}$ The reaction mixture contained $60 \mathrm{~mm}$ potassium

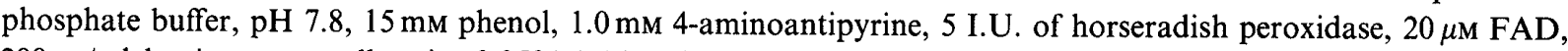
$200 \mu \mathrm{g} / \mathrm{ml}$ bovine serum albumin, $0.05 \%$ (v/v) Triton X-100, $50 \mu \mathrm{M}$ palmitoyl-CoA and the enzymes in $1 \mathrm{ml}$ total volume. The increase in absorbance at $500 \mathrm{~nm}$ was measured at $30^{\circ} \mathrm{C}$. A molar extinction coefficient of $6390 \mathrm{M}^{-1}$ for the complex of phenol and 4-aminoantipyrine was used. The activity of carnitine acetyltransferase (CAT) was determined spectrophotometrically by using DTNB as described by Fritz and Schultz. ${ }^{14)}$ A molar extinction coefficient of $13600 \mathrm{M}^{-1}$ for 5-thio-2-nitrobenzoate at $\mathrm{pH} 8.0$ was used. The unit of these two enzyme activities was expressed in terms of $\mathrm{nmol}$ of product/min. Cytochrome c oxidase activity was determined by the method of Wharton and Tzagoloff. ${ }^{15)}$ Protein concentration was determined by the method of Lowry et al. with bovine serum albumin as a standard. ${ }^{16)}$

Cell Fractionation and Sucrose Density Gradient Centrifugation_- The liver homogenate was fractionated using the method of De Duve et al. ${ }^{17)}$ Nuclear, mitochondrial, light mitochondrial, microsomal and soluble fractions were obtained by centrifugation at $600 \times g$ for $10 \mathrm{~min}, 3300 \times g$ for $10 \mathrm{~min}, 12500 \times g$ for $20 \mathrm{~min}$, and $100000 \times g$ for $60 \mathrm{~min}$, respectively. Then, $3 \mathrm{ml}$ of the light mitochondrial fraction (equivalent to $0.5 \mathrm{~g}$ original tissue $/ \mathrm{ml}$ ) was centrifuged in a sucrose density gradient, formed discontinuously in $60 \mathrm{ml}$ tubes from the bottom to the top with the following solutions; $10 \mathrm{ml}$ of $54.5 \%$ (w/w, density, $1.263 \mathrm{~g} / \mathrm{ml}), 17 \mathrm{ml}$ of $45.6 \%(1.215 \mathrm{~g} / \mathrm{ml}), 12 \mathrm{ml}$ of $38.2 \%$ $(1.174 \mathrm{~g} / \mathrm{ml}), 10 \mathrm{ml}$ of $23.3 \%(1.100 \mathrm{~g} / \mathrm{ml})$ in $20 \mathrm{~mm}$ glycylglycine, $\mathrm{pH} 7.4$. Centrifugation was carried out for $2.5 \mathrm{~h}$ at $24000 \mathrm{rpm}$ at $4{ }^{\circ} \mathrm{C}$ with a swinging-bucket rotor (Hitachi RPS 25-2). Samples were recovered in $4 \mathrm{ml}$ fractions, collected with the aid of a micropump.

\section{Results}

In Table I, the effects of oral administration of phytol on the biochemical values are shown. No increase in liver weight was found in the rats treated with this compound. The

TABLE I. Effects of Phytol on Biochemical Values of Rats

\begin{tabular}{|c|c|c|c|c|c|c|}
\hline \multirow{2}{*}{ Treatment } & \multirow{2}{*}{$\begin{array}{c}\text { Body weight } \\
\text { change } \\
(+\Delta \mathrm{g})\end{array}$} & \multirow{2}{*}{$\begin{array}{l}\text { Liver weight } \\
(\mathrm{g} / 100 \mathrm{~g} \mathrm{bw})\end{array}$} & \multicolumn{2}{|c|}{ Triglyceride } & \multicolumn{2}{|c|}{ Cholesterol } \\
\hline & & & $\begin{array}{l}\text { Serum } \\
(\mathrm{mg} / \mathrm{dl})\end{array}$ & $\begin{array}{l}\text { Liver } \\
(\mathrm{mg} / \mathrm{g})\end{array}$ & $\begin{array}{c}\text { Serum } \\
(\mathrm{mg} / \mathrm{dl})\end{array}$ & $\begin{array}{c}\text { Liver } \\
(\mathrm{mg} / \mathrm{g})\end{array}$ \\
\hline Control & $112 \pm 6$ & $4.4 \pm 0.6$ & $69.9 \pm 6.8$ & $9.0 \pm 0.9$ & $89.6 \pm 4.7$ & $7.4 \pm 0.4$ \\
\hline Phytol $(200 \mathrm{mg} / \mathrm{kg})$ & $\begin{array}{c}105 \pm 6 \\
\mathrm{NS}\end{array}$ & $\begin{array}{c}4.1 \pm 0.4 \\
\mathrm{NS}\end{array}$ & $\begin{array}{c}54.7 \pm 5.0 \\
p<0.01\end{array}$ & $\begin{array}{c}9.7 \pm 0.6 \\
\mathrm{NS}\end{array}$ & $\begin{array}{c}76.4 \pm 5.0 \\
p<0.01\end{array}$ & $\begin{array}{c}7.7 \pm 0.5 \\
\text { NS }\end{array}$ \\
\hline Phytol $(500 \mathrm{mg} / \mathrm{kg})$ & $\begin{array}{c}107 \pm 8 \\
\mathrm{NS}\end{array}$ & $\begin{array}{c}4.2 \pm 0.3 \\
\mathrm{NS}\end{array}$ & $\begin{array}{c}47.7 \pm 5.3 \\
p<0.01\end{array}$ & $\begin{array}{c}11.2 \pm 0.9 \\
p<0.05\end{array}$ & $\begin{array}{c}58.2 \pm 8.3 \\
p<0.01\end{array}$ & $\begin{array}{l}8.8 \pm 0.7 \\
p<0.05\end{array}$ \\
\hline
\end{tabular}

Values represent means $\pm \mathrm{SD}$. Statistical evaluations were performed by Student's $t$-test; NS means not significant $(p>0.05)$. 
substance reduced the TG and cholesterol levels in serum dose-dependently, whereas in the liver the levels were only slightly higher than in the untreated control. Total protein content was not affected by the treatment. Table II shows the effects of the substance on peroxisomal enzymes and on enzymes related to fatty acid metabolism in rat liver. After phytol treatment, depending upon the dosage, the activities of catalase and DAAO, well known peroxisomal enzymes, were increased 1.2- to 1.5-fold, and 1.5- to 1.9-fold, respectively, although no significant change in the activity of urate oxidase was observed. The activity of fatty acyl-CoA oxidase, a key enzyme of peroxisomal $\beta$-oxidation, was increased about 1.3- to 1.4-fold by

Table II. Effects of Phytol on Some Peroxisomal Enzymes of Rat Liver

\begin{tabular}{lccccc}
\hline \hline \multirow{2}{*}{ Treatment } & \multicolumn{5}{c}{ Activity (U/g liver) } \\
\cline { 2 - 6 } & Catalase & DAAO & Urate oxidase & FAO & CAT \\
\hline Control & $28.8 \pm 5.0$ & $0.577 \pm 0.180$ & $2.58 \pm 0.53$ & $303 \pm 27$ & $850 \pm 28$ \\
Phytol $(200 \mathrm{mg} / \mathrm{kg})$ & $34.8 \pm 3.0$ & $0.890 \pm 0.100$ & $2.50 \pm 0.44$ & $391 \pm 40$ & $910 \pm 55$ \\
& $p<0.05$ & $p<0.001$ & $\mathrm{NS}$ & $p<0.01$ & NS \\
Phytol $(500 \mathrm{mg} / \mathrm{kg})$ & $41.7 \pm 3.0$ & $1.070 \pm 0.096$ & $2.68 \pm 0.22$ & $413 \pm 34$ & $1120 \pm 144$ \\
& $p<0.01$ & $p<0.001$ & $\mathrm{NS}$ & $p<0.01$ & $p<0.05$ \\
\hline
\end{tabular}

Values represent means \pm SD. Statistical evaluations were performed by Student's $t$-test; NS means not significant $(p>0.05)$.

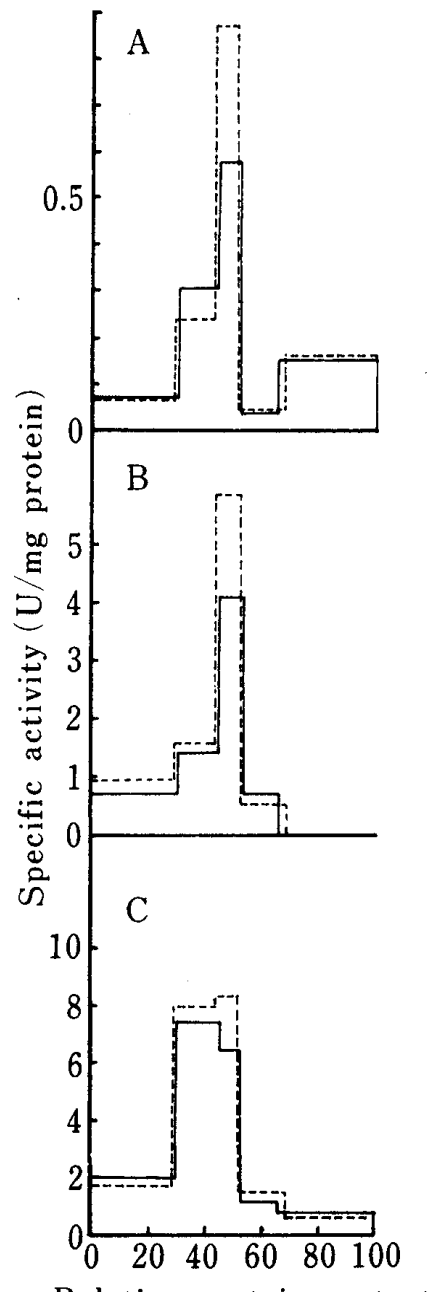

Relative protein content

$(\%)$

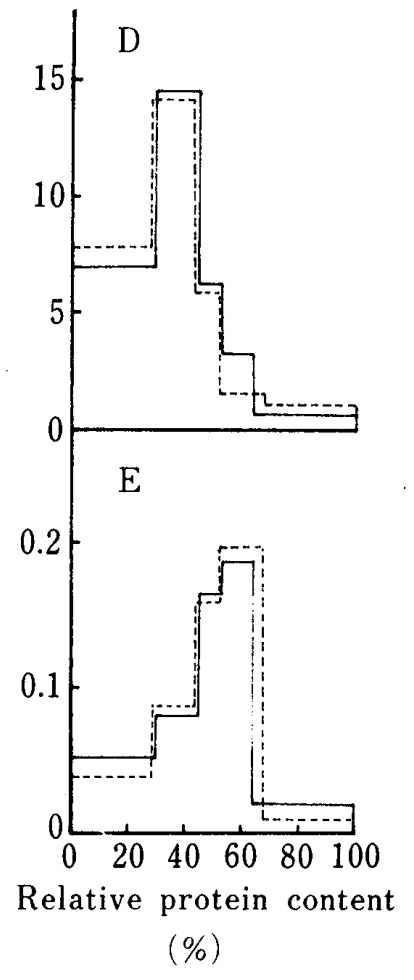

Fig. 1. Subcellular Distributions of Enzymes in the Livers of Control Rats and Rats Given $500 \mathrm{mg} / \mathrm{kg}$ Phytol Daily for 3 Weeks

Fractions are nuclear, mitochondrial, light mitochondrial, microsomal and supernatant, in that order, from the left. Solid lines indicate the control rats and dotted lined indicate treated rats. A, catalase; B, fatty acyl-CoA oxidase; $\mathrm{C}$, carnitine acetyltransferase; D, cytochrome c oxidase; E, glucose-6-phosphatase. 
phytol. The activity of CAT was only slightly increased by phytol at $500 \mathrm{mg} / \mathrm{kg}$. The results of subcellular fractionation of the liver homogenate obtained from control and treated $(500 \mathrm{mg} / \mathrm{kg})$ animals are summarized in Fig. 1. The highest specific activity of catalase, the marker enzymes for peroxisomes, was found in the light mitochondrial (LM) fraction. The highest specific activity of cytochrome c oxidase, the marker enzyme for mitochondria, was found in the mitochondrial (M) fraction. The highest specific activity of glucose-6phosphatase, the marker enzyme for microsomes, was found in the microsomal (P) fraction. The specific activity of FAO, as well as the activity of catalase, was highest in the light mitochondrial fraction. However, no activity of FAO was found in the soluble (S) fraction. The subcellular distribution patterns of these enzymes are in accord with previous results. ${ }^{18)}$

Figure 2 shows the distributions of catalase, FAO, CAT and cytochrome c oxidase activities and protein amount after sucrose density gradient centrifugation. The activity of catalase appeared at around fraction 3 and the activity of cytochrome coxidase appeared at around fraction 7 , showing that peroxisomes and mitochondria well separated. Similar results were obtained in both control and treated rats. In this sucrose gradient centrifugation, the activity of catalase also appeared in the top fraction. This activity may be due to catalase released from peroxisomes disrupted during the experiment. After the phytol treatment, the activities of catalase and FAO were significantly increased in the peroxisomal fraction,

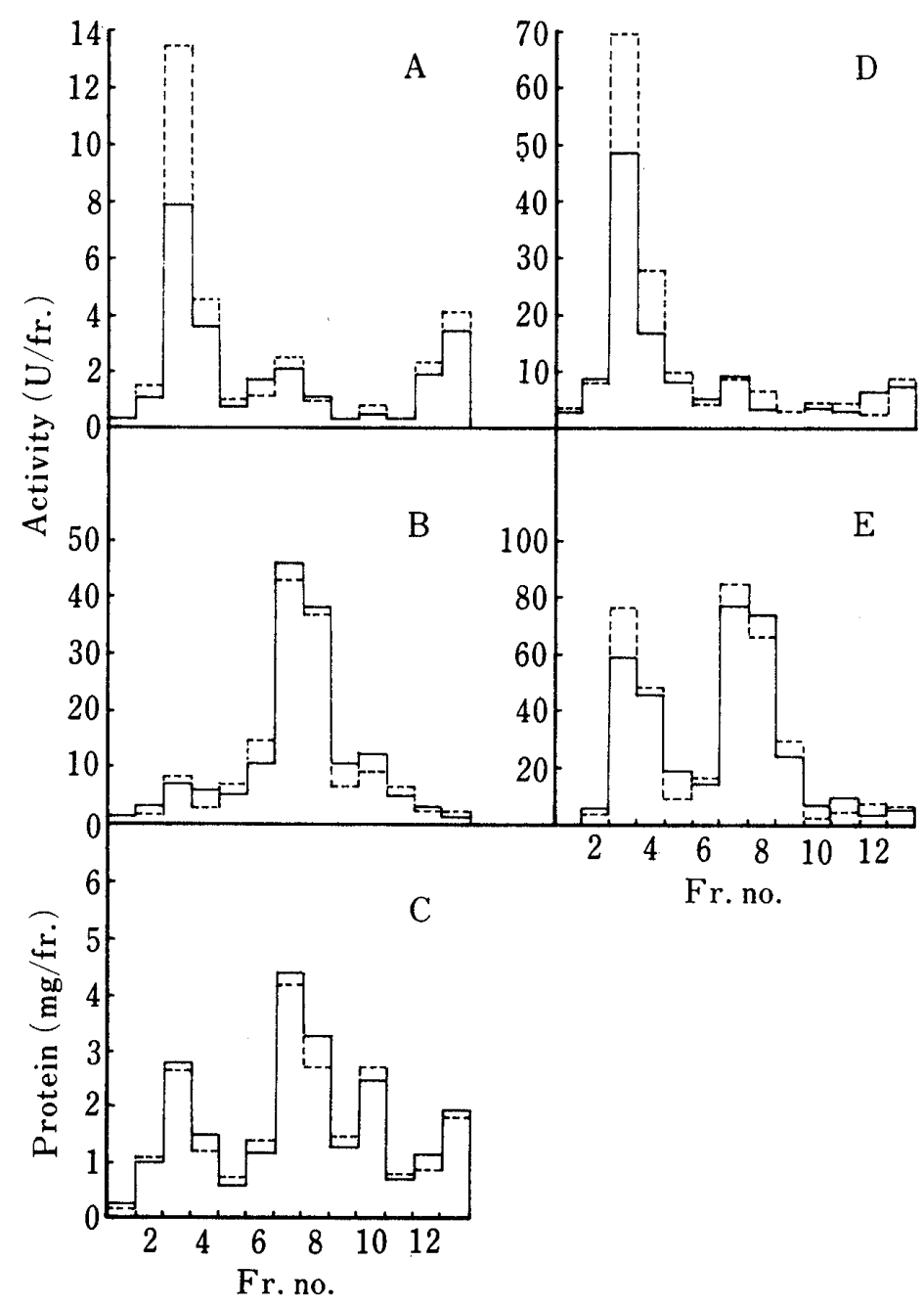

Fig. 2. Sucrose Density Gradient Centrifugation of the Light Mitochondrial Fraction of the Livers of Control and Phytol-Administered Rats

Solid lines indicate the control rats and dotted lines indicate treated rats. A, catalase; B, cytochrome $\mathrm{c}$ oxidase; $\mathrm{C}$, protein; $\mathrm{D}$, fatty acyl-CoA oxidase; $\mathrm{E}$, carnitine acetyltransferase. 
whereas the activities of cytochrome c oxidase and CAT and the protein contents in the peroxisomal and mitochondrial fraction showed little change.

\section{Discussion}

Recent extensive studies on the physiological roles of the peroxisomal $\beta$-oxidation system of animal liver have shown that this system is related to the metabolism of fatty acid, especially long-chain fatty acid. ${ }^{2,3)}$ Furthermore, Pedersen ${ }^{8)}$ demonstrated the participation of the $\beta$-oxidation system of rat liver peroxisomes in the oxidative cleavage of the cholesterol side chain, suggesting that the peroxisomal $\beta$-oxidation system is responsible for not only the degradation of fatty acids but also the metabolism of cholesterol. Many substances, such as vitamin $\mathrm{E}$, which have a branched, long-chain aliphatic group as a side chain are present in animal bodies.

It would be interesting to know whether the peroxisomal $\beta$-oxidation system of the liver also participates in the metabolism of these substances. Phytol, examined in this experiment, is a branched long-chain aliphatic alcohol contained in many plants and is incorporated by feeding into animals. Steinberg et al. ${ }^{9)}$ showed that phytol incorporated into the body is readily oxidized to phytanic acid, subsequently oxidized to pristanic acid through $\alpha$-oxidation with hydrogen peroxide as the oxidizing agent, and then metabolized to acetyl-CoA, propionyl-CoA and isobutyryl-CoA by the $\beta$-oxidation system. In patient with Refsum' disease, this $\beta$-oxidation system is defective, causing an accumulation of phytanic acid.

In this report, we describe the effects of phytol on the rat liver peroxisomal enzymes. With the exception of urate oxidase, the activities of peroxisomal enzymes (catalase, DAAO, FAO and CAT) were significantly increased and these results were confirmed by subcellular fractionation and sucrose density gradient centrifugation. These findings show that phytol incorporated into the liver induces the $\beta$-oxidation system of liver peroxisomes, suggesting that the peroxisomal $\beta$-oxidation system might be involved in the metabolism of phytol. Phytol decreased the levels of serum cholesterol and serum TG. This effect of phytol on serum cholesterol may be a result of the inhibition of absorption of dietary cholesterol. However, the reason for the decreasing effect of phytol on serum TG is not clear, although the stimulation of peroxisomal $\beta$-oxidation activity may be involved. On the other hand, the levels of liver cholesterol and TG were increased.

Finally, these results show that phytol has hypolipidemic activity and activity to induce certain liver peroxisomal enzymes.

We intend to examine in more detail the metabolic pathway of phytanic acid by the use of purified preparations of peroxisomes obtained from the livers of phytol-administered animals.

\section{References}

1) P. B. Lazarow and C. De Duve, Proc. Natl. Acad. Sci. U.S.A., 73, 2043 (1978).

2) R. Z. Christiansen, H. Osmundsen, B. Borrebaek and J. Bremer, Lipids, 13, 487 (1978).

3) H. Osmundsen, C. E. Neat and K. R. Norum, FEBS Lett., 99, 292 (1977).

4) H. Ishii, S. Horie and T. Suga, J. Biochem. (Tokyo), 87, 1855 (1980).

5) H. Ishii, N. Fukumori, S. Horie and T. Suga, Biochim. Biophys. Acta, 617, 1 (1980).

6) C. E. Neat, M. S. Thomassen and H. Osmundsen, Biochem. J., 186, 369 (1980).

7) S. Horie, H. Ishii and T. Suga, J. Biochem. (Tokyo), 90, 1691 (1981).

8) J-I. Pedersen and J. Gustafsson, FEBS Lett., 121, 345 (1980).

9) S-C, Tsai, J. Avigan and D. Steinberg, J. Biol. Chem., 244, 2682 (1969).

10) H. Ishii, T. Suga and S. Niinobe, Biochem. Pharmacol., 25, 1438 (1976).

11) M. Kitamura, Rinsho Kagaku, 1, 19 (1971).

12) H. Hayashi, T. Suga and S. Niinobe, Biochim. Biophys. Acta, 252, 58 (1971).

13) C. C. Allain, L. S. Poon, C. S. G. Chan, W. Richmond and C. Fu, Clin. Chem., 20, 470 (1974). 
14) J. B. Fritz and S. K. Schultz, J. Biol. Chem., 240, 2188 (1965).

15) D. C. Wharton and A. Tzagoloff, "Methods in Enzymology," Vol. 10, Academic Press, New York, 1967, p. 245.

16) O. H. Lowry, N. J. Rosebrough, A. L. Farr and R. J. Randall, J. Biol. Chem., 193, 265 (1951).

17) C. De Duve, B. C. Pressman, R. Gianetto, R. Wattiaux and F. Appelmans, Biochem. J., 60, 604 (1955).

18) H. Hayashi, T. Suga and S. Niinobe, J. Biochem. (Tokyo), 77, 1199 (1975). 